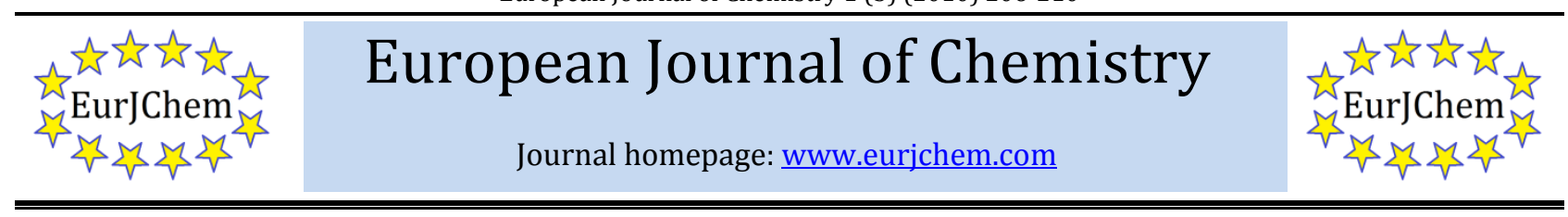

\title{
Extraction of natural color component from the bark of Belleric myrobalan (Terminalia bellerica): Kinetic and adsorption studies
}

\author{
Konaghatta Narayanachar Vinoda, Puttaswamya,, \\ Kurikempanadoddi Ninge Gowdab and Rajagopal Sudhakarb \\ a Department of Chemistry, Bangalore University, Central College Campus, Bangalore, 560001, India \\ bDepartment of Apparel Technology and Management, Bangalore University, Central College Campus, Bangalore, 560001, India \\ ${ }^{*}$ Corresponding author at: Department of Chemistry, Bangalore University, Central College Campus, Bangalore, 560001, India. Tel.: +91.80.22961340; fax: \\ +91.80.22961331. E-mail address: pswamy chem@yahoo.com (Puttaswamy).
}

\section{ARTICLE INFORMATION}

Received: 02 February 2010

Received in revised form: 27 May 2010

Accepted: 01 August 2010

Online: 30 September 2010

\section{KEYWORDS}

\section{Baicalein}

Terminalia bellerica

Identification

Adsorption-kinetics

Thermodynamics

\section{Introduction}

Synthetic dyes that are extensively used in the processes of dyeing are known to release a large amount of residual dyes. Many of these dyes are toxic, even carcinogenic, and hence pose a considerable hazard to aquatic as well as human life. In view of this, replacing synthetic dyes with natural colorants could be considered a better alternative since natural colorants are ecofriendly and also exhibit better biodegradability [1]. A majority of the natural dyes are derived from various parts of trees [24]. Terminalia bellerica (T. bellerica), commonly known as belleric myrobalan, is an important deciduous, medicinal tree belonging to the family of Combretaceae. The fruit and heartwood of $T$. bellerica are known to possess antimicrobial properties [5-6] and are commonly used as traditional medicine for several ailments such as fever, cough, diarrhea, skin diseases and oral thrush [7-8].

In India, the T. bellerica tree is also of great importance as a source of timber [9]. As a part of our on-going research [10] on the identification of color components from tree sources, we extracted and identified a color component from the bark of the T. bellerica tree.

In this study, a silk fabric was dyed using the extracted natural dye and the dyeing process was carried out through adsorption-kinetics. The kinetic and adsorption aspects of dyeing process are very significant in understanding the adsorption process of the natural colorant [11-12].

\section{Experimental}

\subsection{Materials}

The fresh bark of $T$. bellerica was collected from the western parts of Karnataka (Shimoga district), India. The bark was washed with tap water and dried under ambient conditions. The dried bark was cut into small pieces and ground to a fine powder. An open bath beaker dyeing machine equipped with a programmable control of temperature and time was used to carry out this study. Raw silk yarn of 40 denier was used. All solvents, reagents and chemicals used were of Analar grade.

\subsection{Methods}

\subsubsection{Isolation}

For extraction of the color component from T. bellerica bark, the powder (1000 g) was subjected to boiling with distilled water at $90{ }^{\circ} \mathrm{C}$ for $3 \mathrm{~h}$ in a beaker. The extract was collected and distilled water was added repeatedly till the color in the extract became negligible. The total extract was then concentrated under reduced pressure to obtain a solid mass. The solid mass was subjected to extraction with $80: 20 \mathrm{v} / \mathrm{v}$ ethyl alcohol:water mixture, and filtered. The filtrate was evaporated under reduced pressure to get a concentrated mass. Approximately $20 \mathrm{~g}$ of dye concentrate obtained was chromatographically separated in an open column of silica gel (60-120 mesh) in benzene and eluted with benzene, ethyl acetate and methanol in increasing ratios of polarity. The elution with benzene:ethyl acetate $(1: 10)$ resulted in a major pale yellow colored fraction. After evaporation of the solvent from the fraction, an amorphous powder was obtained. 


\subsubsection{Spectral techniques}

The Infra-red spectrum (IR) was recorded on a PerkinElmer 258 spectrophotometer using $\mathrm{KBr}$ pellets. The absorbance of the dye solution was measured using Shimadzu 1700 UV-Visible spectrophotometer. The NMR spectrum of the sample was recorded on spect 400 NMR spectrophotometer. The mass spectral analysis was done using an Esquire-3000 plus spectrophotometer.

\subsubsection{Determination of absorbance and color strength measurements}

Dye solutions containing 1-5 \% were prepared and known amounts were taken in the dye bath by maintaining the material to liquor $(\mathrm{M}: \mathrm{L})$ ratio at 1:20. The absorbance of the dye solution was recorded before and after the dyeing process with UV-Vis spectrophotometer. The amount of dye uptake was calculated using the equation:

$\%$ Dye absorbance $=\frac{\text { Absorbance before dyeing }- \text { Absorbance after dyeing }}{\text { Absorbance before dyeing }} \times 100$

The color strength (K/S values) of the dyed samples was evaluated from the light reflectance technique using KubelkaMunk equation [13]:

$\mathrm{K} / \mathrm{S}=(1-\mathrm{R})^{2} / 2 \mathrm{R}$

where $\mathrm{R}$ is the reflectance; $\mathrm{K}$, the absorption coefficient; and S, the light scattering coefficient.

\subsubsection{Methods of mordanting}

The pre-mordanting and post-mordanting methods were employed at $70{ }^{\circ} \mathrm{C}$ for 30 min using 2, 4 and $6 \%$ solutions of tannic acid and alum $\left(\mathrm{Al}_{2}\left(\mathrm{NH}_{4}\right)_{2}\left(\mathrm{SO}_{4}\right)_{4} \cdot 12 \mathrm{H}_{2} \mathrm{O}\right)$, as mordants separately. The silk was then washed repeatedly with water and dried.

\subsubsection{Dyeing experiments}

The silk yarn was dyed at $\mathrm{pH} 4$ in a bath containing $4 \%$ dye keeping the M:L ratio of 1:20. The dyeing process was started initially at $40{ }^{\circ} \mathrm{C}$ and the temperature was then gradually raised to $90{ }^{\circ} \mathrm{C}$ within $20 \mathrm{~min}$ and the process was continued for 45 min. After this time, the silk was taken out, rinsed in tap water and soaped at $60{ }^{\circ} \mathrm{C}$ for $10 \mathrm{~min}$. Then it was again thoroughly washed with water and dried. For post-mordanting, samples were soaped after mordanting.

\subsubsection{Measurement of colorimetric data}

Colorimetric data of the dyeing process were derived using a spectrophotometer interfaced to a PC. These data were recorded with the specular component of the light excluded and the UV component included, using illuminant $\mathrm{D}_{65}$ and $10^{\circ}$ standard observer.

\subsubsection{Measurement of fastness properties}

Color fastness tests to light, washing and crocking were carried out. The color fastness of the dyed silk to washing was tested by ISO 105-C10:2006 method. The color fastness to crocking was assessed using AATCC Test Method 8-1996 by a crock meter. Color fastness to light was evaluated as per AATCC Test Method 16-2004 option 5.

\section{Results and Discussion}

\subsection{Spectral characterization of color component}

IR spectrum (in $\mathrm{cm}^{-1}$ ) shows peaks at $3410(\mathrm{O}-\mathrm{H}), 2972$ (C$\mathrm{H}), 1654(\mathrm{C}=0)$ and $1618(\mathrm{C}=\mathrm{C}) .{ }^{13} \mathrm{C}$ NMR spectrum in DMSO-d6 shows a peaks at $\delta 182$ (C-4), 163 (C-7), 152 (C-2), 150 (C-5), 145 (C-9), 130 (C-4'), 128 (C-32'), 128 (C-5'), 125 (C-1'), 103 (C-22'), 103 (C-6'), 93 (C-8). ${ }^{1} \mathrm{H}$ NMR spectrum in DMSO-d6 shows peaks at $\delta 12.5(\mathrm{~s}, 1 \mathrm{H}, \mathrm{H}-5), 10.8(\mathrm{~s}, 1 \mathrm{H}, \mathrm{H}-6), 9.64(\mathrm{~s}, 1 \mathrm{H}$, H-7), 7.51 (s, 2H, H-3', 5'), 6.8 (s, 1H, H-3), 6.3 (d, 1H, H-8). Mass spectrum $(\mathrm{m} / \mathrm{z})$ in positive mode shows a peak at $271 \mathrm{amu}$ $(\mathrm{M}+\mathrm{H})^{+}$, indicating that the color compound has a molecular weight of $270 \mathrm{amu}$, which is a characteristic of Baicalein $\left(\mathrm{C}_{15} \mathrm{H}_{10} \mathrm{O}_{5}\right)$ [14-16] (Figure 1).<smiles>O=c1cc(-c2ccccc2)oc2cc(O)c(O)c(O)c12</smiles>

\subsection{Effect of concentration of dye on absorption and color strength on dyeing}

The absorbance and color strength values $(\mathrm{K} / \mathrm{S})$ increased with an increase in the concentration of the dye in the concentration range of 1 to $5 \%$. Table 1 reveals that the dye uptake percentage and $\mathrm{K} / \mathrm{S}$ values reached a maximum at $4 \%$ dye concentration (Figure 2) and hence this dye concentration was fixed as optimal for the process of dyeing.

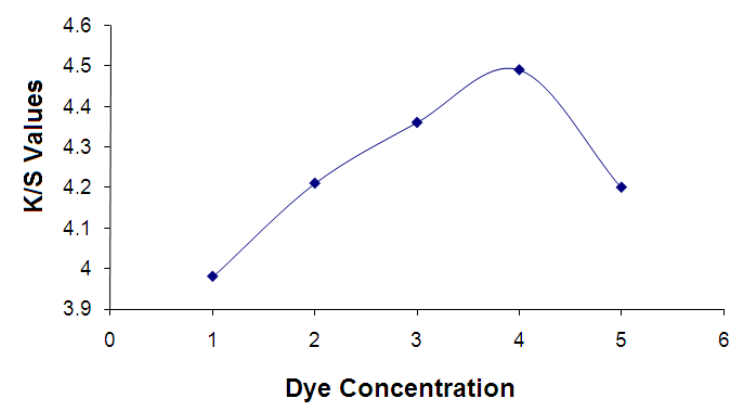

Figure 2. A plot of K/S values versus concentration.

Table 1. Values of absorbance and K/S of different dye concentrations.

\begin{tabular}{lcccc}
\hline $\begin{array}{l}\text { Dye } \\
\text { (\%) }\end{array}$ & \multicolumn{2}{c}{ Absorbance } & \multirow{2}{*}{ Dye uptake (\%) } & \multirow{2}{*}{ K/S } \\
\cline { 2 - 3 } $\mathbf{1}$ & 0.30 & 0.21 & 30.0 & 3.98 \\
2 & 0.61 & 0.40 & 34.4 & 4.21 \\
3 & 0.93 & 0.60 & 35.0 & 4.36 \\
4 & 1.24 & 0.80 & 35.5 & 4.49 \\
5 & 1.51 & 0.99 & 34.4 & 4.20 \\
\hline
\end{tabular}

\subsection{Effect of mordanting on dyeing}

Tables 2 and 3 show that the values of K/S and properties of fastness increased more with mordanting compared to unmordanting. The pre-mordanting technique was found to be better as it improved $\mathrm{K} / \mathrm{S}$ values and fastness properties compared to the post-mordanting technique. It was also observed that $\mathrm{K} / \mathrm{S}$ values increased with the increase in concentration of alum in the case of pre-mordanting. This indicates that alum is a better mordant compared to tannic acid as it shows better color values and fastness properties. 
Table 2. Values of color strength (K/S) and color co-ordinates of dyed samples.

\begin{tabular}{|c|c|c|c|c|c|c|c|}
\hline Method & Mordants & $\mathrm{K} / \mathrm{S}$ & $\mathbf{L}^{*}$ & $\mathbf{a}^{*}$ & $\mathbf{b}^{*}$ & C & $\mathbf{h}$ \\
\hline \multirow{7}{*}{ Pre } & Nil & 4.49 & 70.7 & 8.60 & 10.7 & 13.8 & 50.1 \\
\hline & Alum $(2 \%)$ & 4.66 & 71.0 & 5.13 & 10.8 & 12.0 & 63.6 \\
\hline & Alum (4\%) & 4.83 & 70.3 & 5.25 & 11.6 & 12.6 & 64.7 \\
\hline & Alum (6\%) & 4.87 & 69.6 & 5.63 & 11.8 & 13.1 & 63.3 \\
\hline & Tannic acid (2\%) & 4.60 & 72.2 & 8.65 & 10.1 & 13.3 & 48.5 \\
\hline & Tannic acid (4\%) & 4.62 & 72.3 & 8.73 & 10.0 & 13.3 & 47.5 \\
\hline & Tannic acid (6\%) & 4.84 & 69.7 & 9.47 & 11.6 & 15.0 & 50.0 \\
\hline \multirow{5}{*}{ Post } & Alum (2\%) & 4.57 & 69.1 & 6.63 & 11.7 & 13.4 & 59.2 \\
\hline & Alum (4\%) & 4.63 & 69.5 & 6.72 & 12.0 & 13.5 & 59.4 \\
\hline & Alum (6\%) & 4.89 & 69.9 & 6.75 & 11.9 & 13.6 & 59.2 \\
\hline & Tannic acid (2\%) & 4.51 & 71.3 & 9.62 & 11.8 & 15.1 & 49.4 \\
\hline & Tannic acid (4\%) & 4.53 & 70.2 & 9.81 & 12.5 & 15.8 & 50.6 \\
\hline
\end{tabular}

Table 3. Fastness ratings of dyed silk samples.

\begin{tabular}{|c|c|c|c|c|c|}
\hline \multirow{2}{*}{ Method } & \multirow{2}{*}{ Mordant } & \multirow{2}{*}{ Light fastness } & \multirow{2}{*}{ Crocking fastness } & \multicolumn{2}{|c|}{ Wash fastness } \\
\hline & & & & Wet & Dry \\
\hline \multirow{7}{*}{ Pre } & Nil & 2 & 4 & $4-5$ & 4 \\
\hline & Alum (2\%) & $2-3$ & $4-5$ & $4-5$ & $4-5$ \\
\hline & Alum (4\%) & $2-3$ & $4-5$ & 5 & $4-5$ \\
\hline & Alum (6\%) & 3 & 5 & 5 & 5 \\
\hline & Tannic acid (2\%) & $2-3$ & $4-5$ & $4-5$ & $4-5$ \\
\hline & Tannic acid (4\%) & $2-3$ & $4-5$ & $4-5$ & $4-5$ \\
\hline & Tannic acid (6\%) & $2-3$ & $4-5$ & 5 & $4-5$ \\
\hline \multirow{6}{*}{ Post } & Alum (2\%) & 2 & 4 & $4-5$ & 4 \\
\hline & Alum (4\%) & 2 & $4-5$ & $4-5$ & $4-5$ \\
\hline & Alum (6\%) & $2-3$ & $4-5$ & $4-5$ & $4-5$ \\
\hline & Tannic acid (2\%) & $2-3$ & 4 & $4-5$ & $4-5$ \\
\hline & Tannic acid (4\%) & $2-3$ & 4 & $4-5$ & $4-5$ \\
\hline & Tannic acid $(6 \%)$ & $2-3$ & $4-5$ & $4-5$ & $4-5$ \\
\hline
\end{tabular}

The color co-ordinates observed were positive and lie in the yellow-red quadrant of the color space diagram. The color coordinates, color strength values and the fastness properties of the dyed samples determined that the extract is a good source of natural dye for silk.

\subsection{Effect of pH on dye extract}

The visible spectrum of the dye extract at different $\mathrm{pH}(4,7$ and 9) is shown in Figure 3, which reveals that the $\lambda_{\max }$ of the dye extract did not change with varying $\mathrm{pH}$. The absorbance of the dye extract increased with increase in $\mathrm{pH}$, which may be due to the high solubility of phenolic groups in the alkaline $\mathrm{pH}$.

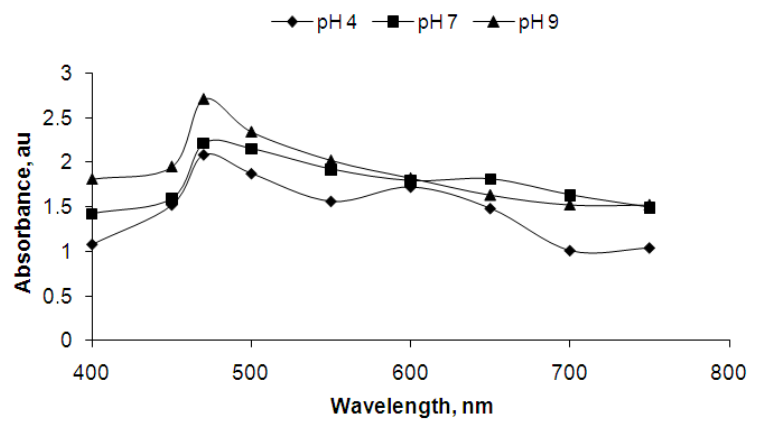

Figure 3. Visible spectra of the dye extract at $\mathrm{pH} 4,7$ and 9.

\subsection{Kinetic studies}

In order to understand the rate of dye uptake by silk, kinetic studies were carried out using un-mordanted silk with aqueous solution of the extract. Extract solution was prepared by dissolving $0.5 \mathrm{~g} \mathrm{dm}^{-3}$ of extract in an acetate buffer of $\mathrm{pH} 4$. The dyeing process was carried out with ML ratio of 1:20 at 50 ${ }^{\circ} \mathrm{C}$. Known volume (5 $\mathrm{mL}$ each) of the dyeing solution was pipetted into a cuvette at regular intervals of time $(5 \mathrm{~min})$ and absorbance measurements were made at its $\lambda_{\max }$ of $470 \mathrm{~nm}$ (Figure 3). The absorbance readings at $\mathrm{t}=0$ and $\mathrm{t}=\mathrm{t}$ are $\mathrm{D}_{\mathrm{o}}$ and $D_{\mathrm{t}}$. First-order rate constants $\left(k^{\prime}, \mathrm{s}^{-1}\right)$ for adsorption were evaluated by $\log \left(D_{o} / D_{t}\right)$ vs. time plots. The experiment was repeated at $60,70,80$, and $90{ }^{\circ} \mathrm{C}$ and the rate of adsorption was calculated at each temperature. From the linear Arrhenius plot of $\log k^{\prime}$ vs. $1 / \mathrm{T}\left(\mathrm{R}^{2}=0.9973\right)$, values of activation parameters such as the energy of activation $\left(E_{a}\right)$, enthalpy of activation $\left(\Delta \mathrm{H}^{\ddagger}\right)$, entropy of activation $\left(\Delta \mathrm{S}^{\ddagger}\right)$ and free energy of activation $\left(\Delta G^{\neq}\right)$were computed (Table 4). The positive value of the standard free energy change indicates that the affinity between the dye molecule and the silk fiber is very strong. The positive enthalpy of activation signifies that the dyeing process is endothermic in nature. The large negative entropy of activation perhaps indicates more orderly distribution of the color component of dye on silk during adsorption.

Table 4. Values of thermodynamic parameters for the dyeing process.

\begin{tabular}{ll} 
Temperature $\left({ }^{\circ} \mathbf{C}\right)$ & $\boldsymbol{k}^{\prime} \times \mathbf{~ 1 0}^{4} \mathbf{s}^{-1}$ \\
\hline 50 & 0.64 \\
60 & 1.25 \\
70 & 2.38 \\
80 & 4.61 \\
90 & 9.23 \\
& \\
$E_{a}\left(\mathrm{~kJ} \mathrm{~mol}^{-1}\right)$ & 57.4 \\
$\Delta \mathrm{H}^{\neq}\left(\mathrm{kJ} \mathrm{mol}^{-1}\right)$ & 54.3 \\
$\Delta \mathrm{G}^{\ddagger}(\mathrm{kJ} \mathrm{mol}-1)$ & 108 \\
$\Delta \mathrm{S}^{\ddagger}\left(\mathrm{JK}-1 \mathrm{~mol}^{-1}\right)$ & -157 \\
$\log \mathrm{A}$ & 5.10 \\
\hline
\end{tabular}

\subsection{Adsorption isotherm studies}

The distribution of adsorption molecules between the liquid phase and the solid phase at equilibrium can be explained by adsorption isotherm. The amount of dye adsorbed (qe $\mathrm{mg} / \mathrm{g}$ ) at equilibrium was calculated by the following mass balance equation [17]:

$\mathrm{q}_{\mathrm{e}}=\mathrm{V}\left(\mathrm{C}_{\mathrm{i}}-\mathrm{C}_{\mathrm{e}}\right) / \mathrm{m}$

where, $\mathrm{V}$ is the volume of solution used in the adsorption experiment, $\mathrm{C}_{\mathrm{i}}$ and $\mathrm{C}_{\mathrm{e}}$ are the initial and equilibrium concentrations of the dye $\left(\mathrm{mg} \mathrm{dm}^{-3}\right)$ respectively, and $\mathrm{m}$ is the mass of the silk (g).

Langmuir, Freundlich and Tempkin-pyzhev adsorption isotherm models were examined to describe the adsorption 
equilibrium. Langmuir model [18] assumes a homogeneous monolayer adsorption and the linearized Langmuir model is given by the following equation:

$$
\frac{C_{e}}{q_{e}}=\frac{1}{Q_{o} b}+\frac{C_{e}}{Q_{o}}
$$

where $C_{\mathrm{e}}$ is the concentration of the adsorbent $\left(\mathrm{mg} / \mathrm{dm}^{-3}\right)$ at equilibrium; $q_{\mathrm{e}}$ is the amount of dye adsorbed at equilibrium (mg/g); $Q o$ is a constant which signifies the adsorption capacity $(\mathrm{mg} / \mathrm{g})$; and $b$ is the Langmuir constant related to the adsorption energy $\left(\mathrm{dm}^{3} / \mathrm{mg}\right)$.

The plot of $1 / C_{\mathrm{e}}$ vs. $1 / q_{\mathrm{e}}$ gives a straight line with a linear regression coefficient of 0.9793 (Figure 4). From the intercept and slope of such a plot, values of constants $Q_{0}$ and $b$ were evaluated as $66.6 \mathrm{mg} / \mathrm{g}$ and $3.16 \mathrm{dm}^{3} / \mathrm{mg}$, respectively.

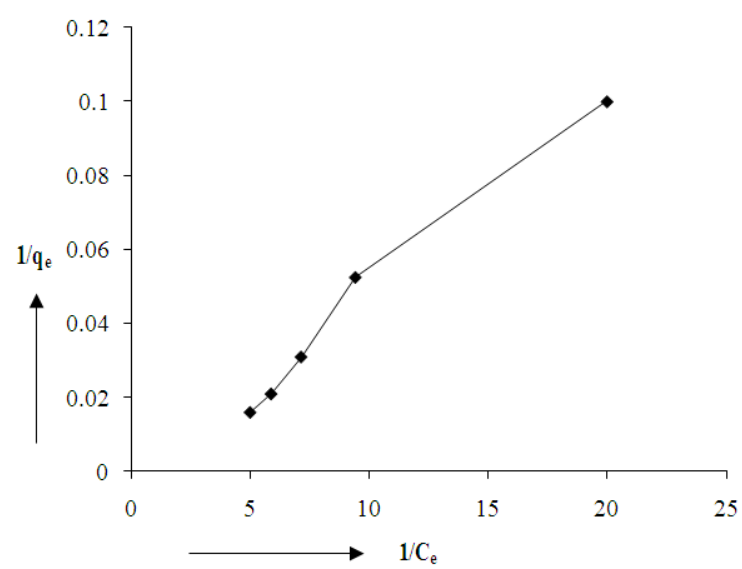

Figure 4. Langmiur isotherm plot for dyeing silk at $80^{\circ} \mathrm{C}$ with $\mathrm{pH} 4$.

Further, the important characteristics of the Langmuir isotherm can be expressed in terms of the dimensionless constant separation factor for equilibrium parameter, $\mathrm{R}_{\mathrm{L}}$ [1920] which is expressed as:

$$
R_{L}=\frac{1}{\left(1+b C_{o}\right)}
$$

The value of $R_{\mathrm{L}}$ indicates the type of isotherm to be either irreversible $\left(R_{\mathrm{L}}=0\right)$, favorable $\left(0<R_{\mathrm{L}}<1\right)$, linear $\left(R_{\mathrm{L}}=1\right)$ or unfavorable $\left(R_{\mathrm{L}}>1\right)$. In the present study, the value of $R_{\mathrm{L}}$ was 0.75 , indicating the Langmiur adsorption isotherm to be a favorable adsorption isotherm.

The Freundlich model assumes a heterogeneous multilayer adsorption surface with sites that have different energies of adsorption which are not equally available. The Freundlich model [21] is:

$\log q_{e}=\log K_{f}+\frac{\log C_{e}}{n}$

where $q_{\mathrm{e}}$ is the amount of dye at equilibrium (mg/g); $C_{\mathrm{e}}$ is the dye concentration in the solution $\left(\mathrm{mg} \mathrm{dm}^{-3}\right)$ at equilibrium; and $K_{\mathrm{f}}$ and $\mathrm{n}$ are Freundlich constants incorporating all factors affecting the adsorption process. In general, as the value of $K_{\mathrm{f}}$ increases the adsorption capacity of the adsorbent for the given adsorbate also increases. $1 / n$ is the heterogeneity factor, if $n$ is close to 1 , the surface heterogeneity could be assumed to be less significant and as $\mathrm{n}$ approaches 10 , the impact of surface heterogeneity becomes more significant [22]. A plot of $\log q_{\mathrm{e}} \mathrm{vs}$. $\log C_{\mathrm{e}}$ was linear with a regression coefficient of 0.9682 (Figure 5). The values of $K_{\mathrm{f}}$ and $1 / n$, were evaluated from such a plot and found to be 5.01 and 1.32, respectively. Further, the value of $1 / n$ is close to unity, suggesting that the adsorption of dye molecules on silk is homogeneous.

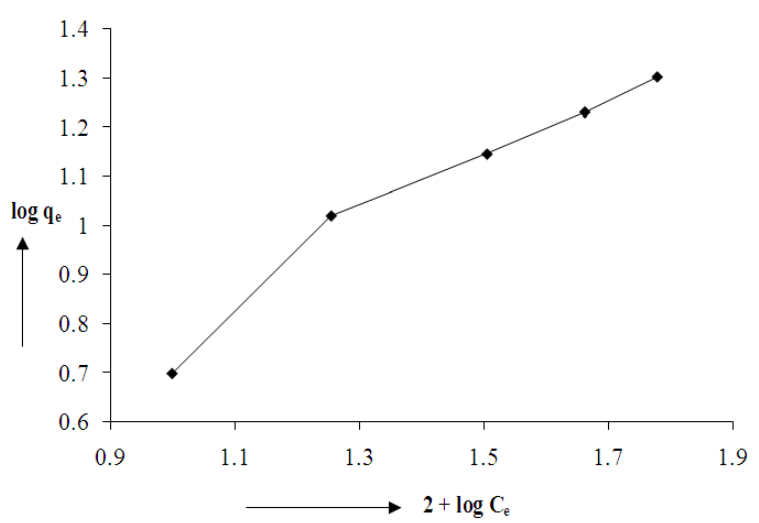

Figure 5. Freundlich isotherm plot for dyeing silk at $80{ }^{\circ} \mathrm{C}$ with $\mathrm{pH} 4$.

The Tempkin and Pyzhev [23] isotherm model was also considered to fit the present experimental data. The Tempkin isotherm can be expressed in its linear form as:

$q_{\mathrm{e}}=\mathrm{B} \ln \mathrm{A}+\mathrm{B} \ln C_{\mathrm{e}}$

where $\mathrm{B}$ and $\mathrm{A}$ are the Tempkin constants and can be determined by a plot of $q_{\mathrm{e}} \mathrm{vs}$. $\ln C_{\mathrm{e}}$. The constant B is related to heat of adsorption and $\mathrm{A}$ is the equilibrium binding constant. $\mathrm{A}$ plot of $q_{\mathrm{e}} \mathrm{vs} . \log C_{\mathrm{e}}$ is curvilinear in nature with a very low regression value of 0.8970 (Figure 6) and hence this model does not fit well with the present system.

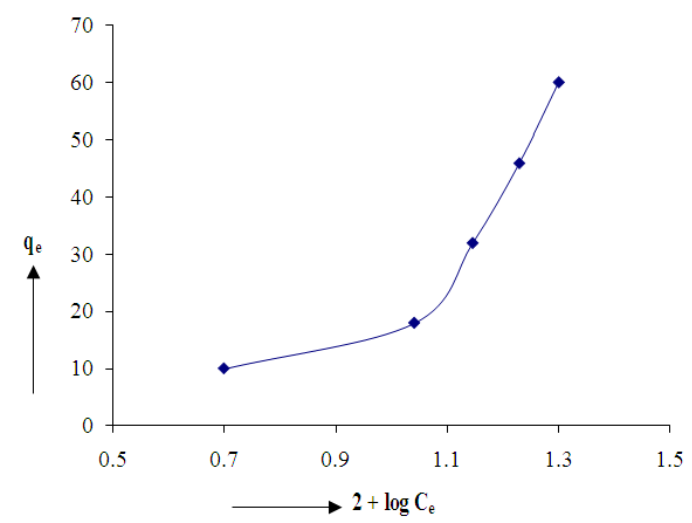

Figure 6. Tempkin-Pyzhev isotherm plot for dyeing silk at $80^{\circ} \mathrm{C}$ with $\mathrm{pH} 4$

The linear regression coefficient was frequently used to decide the most fitted isotherm in the adsorption process. In the present case, the Langmuir model was found to fit better than the other two models with a relatively high regression coefficient $\left(\mathrm{R}^{2}=0.9793\right.$; Figure 4). This indicates that the homogeneous monolayer possibly formed with the interaction between hydroxyl groups of colorant and the amino groups of silk protein. Further, the value of $1 / n(1.32)$ in Freundlich isotherm model also supports the homogeneous adsorption of dye molecules on silk.

\section{Conclusion}

Baicalein, 5,6,7-trihydroxy flavone was found to be a major color component from the bark of $T$. bellerica. The color fastness properties of baicalein on silk in pre-mordanting were found to be appreciable compared to post-mordanting. Thermodynamic parameters were computed by studying the dyeing-kinetics at different temperatures. The enthalpy of 
dyeing was found to be positive, suggesting the endothermic nature of dyeing. The negative value of entropy indicates that the dye molecules were arranged in order on silk. The positive change in free energy shows the affinity between the dye molecules and the protein content of silk. Further, the adsorption isotherm studies were carried out on three isotherms. The Langmuir isotherm was found to be the best fit isotherm with relatively high regression value compared to Freundlich and Tempkin and Pyzhev isotherm models. The adsorption data indicates the formation of homogeneous monolayer possibly with the interaction between hydroxyl groups of Baicalein and the amino groups of silk protein. It can be concluded that $T$. bellerica bark can be used as a source of natural dye for textile dyeing. This kind of research provokes natural dyes in dyeing application.

\section{Acknowledgements}

One of the authors (K.N.V) is grateful to the Bangalore University, Bangalore for awarding the research fellowship under Interdisciplinary Collaborative Research Project.

\section{References}

[1]. Kumar, J. K.; Sinha, A. K. Nat. Prod. Lett. 2004, 18(1), 59-84.

[2]. Cerrato, A.; Santis D. D.; Moresi, M. J. Sci. Food Agric. 2002, 82(10), 1189-1199.

[3]. Angelini, L. G.; Pistelli, L.; Belloni, P.; Bertoli A.; Panconesi, S. Ind. Crops Prod. 1997, 6(3-4), 303-311.

[4]. Angelini, L. G.; Bertoli, A.; Rolandelli S.; Pistelli, L. Ind. Crops Prod. 2003, 17(3), 199-207.

[5]. Elizabeth, K. M. Indian J. Clin. Biochem. 2005, 20(2), 150-153.

[6]. Asati, R. K.; Singhal, M.; Saxena, M. J. Pure Applied Microb. 2008, 2(2), 599-603.

[7]. Kirtikar, K. R.; Basu, B. D. Indian Medicinal Plants. Vol. 2, Dehra Dun, India, 1991.

[8]. Pushpangadan, P.; Atal, C. K. J. Ethnopharmacol. 1986, 16(2-3), 175190.

[9]. Pandey R.; Cahuhan, K. S. J. Timber Develop. Assoc. India. 2001, 47(12), 27-29.

[10]. Vinod, K. N.; Puttaswamy; Ninge Gowda, K. N.; Sudhakar, R. Color. Technol. 2010, 126, 48-53.

[11]. Rattanapani, S.; Chairat, M.; Bremner J. B.; Rattanapani, V. Dyes Pigm. 2007, 72, 88-96.

[12]. Janhom, S.; Griffiths, P.; Watanesk R.; Watanesk, S. Dyes Pigm. 2004 63(3), 231-237.

[13]. Kubelka, P. J. Opt. Soc. Am. 1954, 44(4), 330-334.

[14]. Ronald B. P.; Oszmiañski, R. A. J. Pol. J. Food Nutrit. Sci. 2005, 14/55(1), 43-50.

[15]. Yuan, Y.; Hou, W.; Tang, M.; Luo, H.; Chen, L. J.; Guan, Y. H. Chromatographia. 2008, 68, 885-892.

[16]. Amarowicz, R.; Pegg, R. B.; Kolodziejczyk P. P.; Ski, J. O. J. Liq. Chromatogr. Related Technol. 2004, 27(18), 2847-2860.

[17]. Alkan, M.; Dogan, M.; Turhan, Y.; Demirbas O.; Turan, P. Chem. Eng. J. 2008, 39(2), 213-223.

[18]. Saeid, A.; Monireh, H.; Hadis, B. Chem. Eng. J. 2009, 146, 36-41.

[19]. Jain, A. K.; Gupta, V. K.; Suhas, A. B. J. Hazard. Mater. 2003, 101(1), 3142.

[20]. Sivaraj, R.; Namasivayam, C.; Kadirvelu, K. Waste Manage. 2001, 21(1), 105-110.

[21]. Runping, H.; Jingjing, Z.; Pan, H.; Yuanfeng, W.; Zhenhui, Z.; Mingsheng, T. Chem. Eng. J. 2009, 145, 496-504.

[22]. Davila, M. M.; Elizalde, M. P.; Pelaez, A. A. Colloids Surf. A. 2005, 254, 107-114.

[23]. Tempkin, M. J.; Pyzhev, V. Acta Physiochim. URSS. 1940, 12, 217-244. 